\title{
A comparison of the causes, effects and aftermaths of the coastal flooding of England in 1953 and France in 2010
}

\author{
D. M. Lumbroso ${ }^{1,2}$ and F. Vinet ${ }^{3}$ \\ ${ }^{1}$ HR Wallingford, Howbery Park, Wallingford, Oxfordshire OX10 8BA, UK \\ ${ }^{2}$ ILUNAM Université, Institut Français des Sciences et Technologies des Transports, \\ de l'Aménagement et des Réseaux (IFSTTAR), GER, 44341 Bouguenais, France \\ ${ }^{3}$ Unité Mixte de Recherche, Gouvernance, Risque, Environnement, Développement (GRED), \\ Institut de Recherche pour le Développement (IRD), Université Paul-Valéry Montpellier III, France
}

Received: 11 March 2011 - Revised: 14 June 2011 - Accepted: 20 July 2011 - Published: 25 August 2011

\begin{abstract}
This paper provides a comparison of the causes, effects and aftermaths of the coastal flooding that occurred on the east coast of England in 1953 and the west coast of France in 2010 that resulted in 307 and 47 deaths respectively. The causes of both events are strikingly similar. Both were caused by a combination of high tides, low atmospheric pressure, high winds and the failure of poorly maintained flood defences. In both cases the number of deaths was related to the vulnerability of the buildings and people. Buildings in the flood zones were often single storey bungalows and the people who died were mostly over $60 \mathrm{yr}$ of age. Both tragedies were national disasters. The 1953 flood in England acted as a catalyst for an acceleration in flood risk management policy and practice. It resulted in: the development of a Storm Tide Warning System for the east coast of England; the setting of new design standards for coastal flood defences; increased investment in improving coastal defences; and a substantial new research effort into coastal processes, protection and forecasting. In France there has also been an episodic shift in flood risk management policy with the focus falling on: control of urban developments in areas at risk of flooding; improved coastal forecasting and warning; strengthening of flood defences; and developing a "culture of risk awareness". This paper outlines the lessons that can be learnt from the two events and provides recommendations concerning how future loss of life as a result of coastal flooding can be reduced.
\end{abstract}

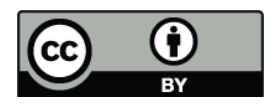

Correspondence to: D. M. Lumbroso (d.lumbroso@hrwallingford.co.uk)

\section{Introduction}

The storm surge that struck the east coast of England and the south-west coast of the Netherlands during the night of Saturday 31 January 1953 caused the worst natural disaster in northern Europe of the past two centuries. In eastern England 307 lives were lost, more than 32000 people were evacuated, 24000 houses were damaged, 46000 livestock were killed, 160000 acres of agricultural land were flooded with salt water, and major transportation links were impassable (Summers, 1978). The damage has been estimated at $£ 5$ billion in today's money (RMS, 2003).

On 28 February 2010 at 2 o'clock in the morning the "tempête" (storm) Xynthia hit the French Atlantic coast. The storm surge combined with a high tide and large waves caused flood defences to fail along the coast from the Gironde near Bordeaux to the Loire Estuary. Over 50000 ha of land were flooded and 47 people died as a result of the storm. Most people died as result of the flooding although a small number of people died as a result of storm debris. The French Departments of Vendée and Charente-Maritime suffered the most damage (Kolen et al., 2010). It has been estimated that the damage caused by the flooding may have cost in excess of $€ 1.2$ billion (Le Figaro, 2010a).

This paper sets out to compare the causes and effects of the two events in England and France including the nature of the flood hazard, the vulnerability of the receptors (i.e. people and buildings) and the consequences. One of the purposes of this comparison is to provide a broad, comparative review of the management of flood risk in the two countries. Over the last $50 \mathrm{yr}$ a wide range of flood risk management measures have reduced the risk of fatalities from flooding in the UK. The selection of mitigation measures implemented has been

Published by Copernicus Publications on behalf of the European Geosciences Union. 


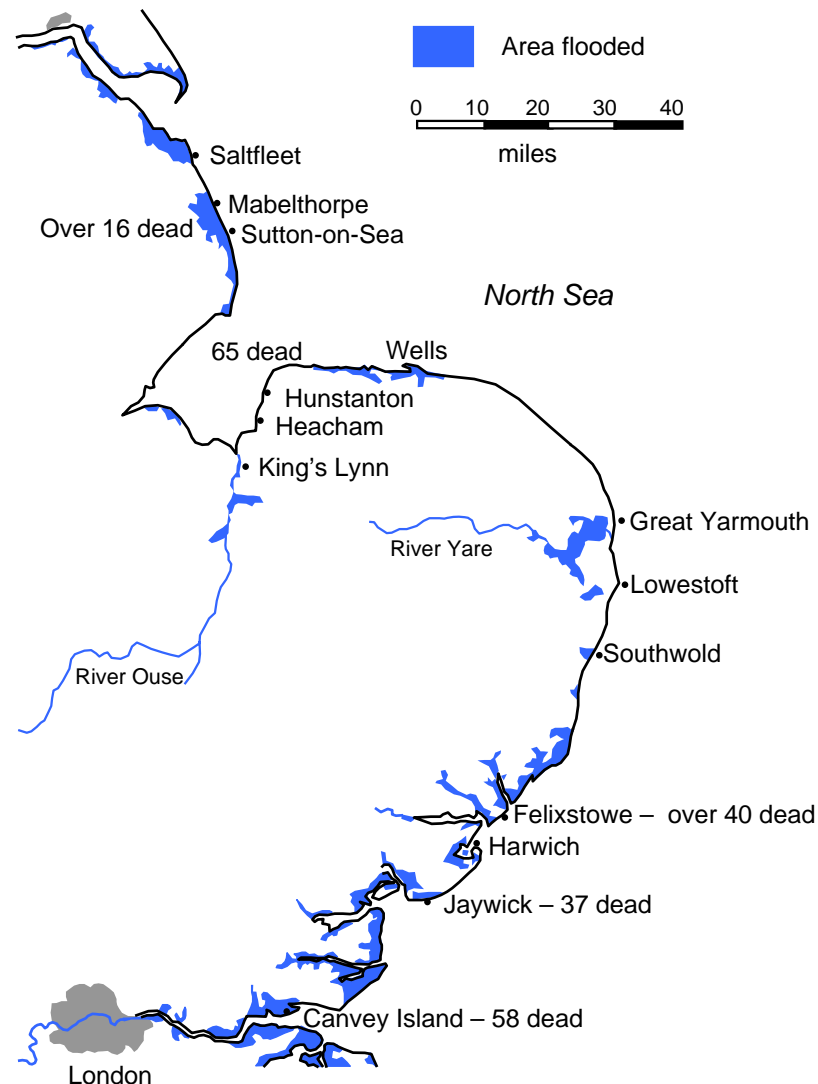

Fig. 1. Area flooded and the loss of life in east England as a result of the 1953 coastal floods.

informed largely by assessing and reducing the flood risk of areas where people live and work, and the infrastructure on which they depend (DEFRA, 2008a). The paper considers whether the lessons learnt and policies adopted by the British Government after the 1953 event are relevant to France and its current policy on flood risk management. The paper also provides a series of conclusions and recommendations.

\section{Nature of the flood hazard}

\subsection{The Great North Sea Floods in England in $\mathbf{1 9 5 3}$}

Storm surges present a very specific type of flood hazard to the east coast of England, a hazard that can be more severe than coastal floods seen elsewhere around the British Isles, mainly because of the semi-enclosed funnel shape, and the shallow nature of the North Sea (Baxter, 2005). The Great North Sea Flood in England was caused by a storm surge that was the result of wind pushing the sea towards the coast, coupled with low air pressure and a high astronomical tide. From 06:00 pm on the evening of 31 January 1953, winds drove the storm surge southwards along the east coast reaching Canvey Island just after midnight on 1 February 1953 (Grieve, 1959).

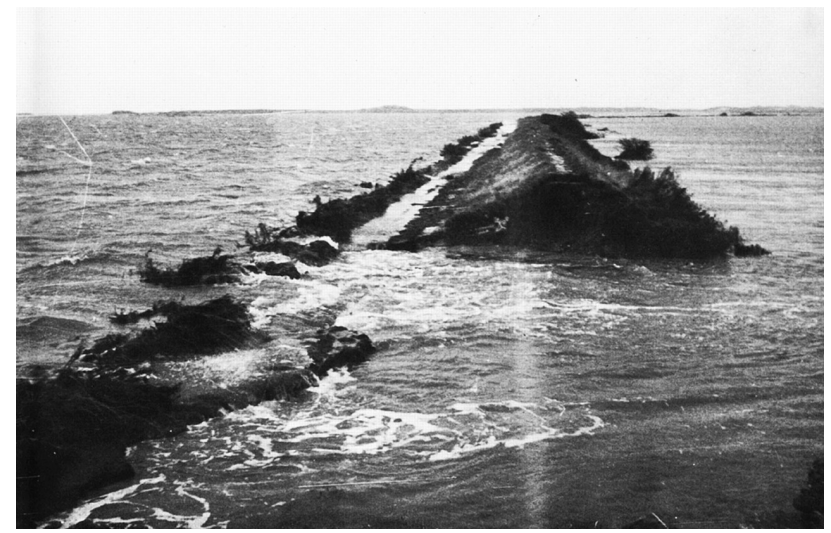

Fig. 2. Typical breach in the flood defences during the 1953 floods.

The high water levels associated with the combination of storm surge and tide had not been foreseen in the design of coastal flood defences, which were unable to hold back the water in many places. The 1953 storm surge produced high water levels not seen for the previous $250 \mathrm{yr}$ along the coast of East Anglia. The surge affected $1600 \mathrm{~km}$ of the coastline of eastern England (Muir Wood et al., 2005).

By the end of World War II, Britain's coastal flood defences were in a fairly neglected state (Kraus, 1996). The Great North Sea Flood highlighted the inadequacy of coastal defences in place in the UK at the time. It caused an estimated 2000 breaches in the natural and artificial flood defences (Muir-Wood et al., 2005). Along the estuaries of Essex, there were 839 breaches up to $45 \mathrm{~m}$ in width and extending from 1.5 to $6 \mathrm{~m}$ in depth below the former defence crest (Cooling and Marsland, 1954).

Several mechanisms contributed to the defence failures. In some cases, the powerful surge and associated waves scoured the seaward face of the defences while water that had overtopped or flowed through cracks and permeable layers eroded the inland face, leading to damage and collapse. Elsewhere, sand and earth fillings were washed out, undermining the embankments leading to their collapse (Muir Wood et al., 2005). People were taken by surprise by the floods owing primarily to the sudden breaching of flood defences and the lack of forecasting and warning systems.

Figure 1 shows the area inundated and the location of the fatalities as a result of the 1953 floods (Steers, 1953). Figure 2 shows a photograph of flood defences that were breached in the 1953 event.

\subsection{Background to the flooding caused by "tempête" Xynthia in France in 2010}

The "tempête" (storm) Xynthia struck the French Atlantic coast at 02:00 am on 28 February 2010. In many respects, the cause of the flooding was very similar to that which occurred in Britain in 1953. In France the coastal defences in 


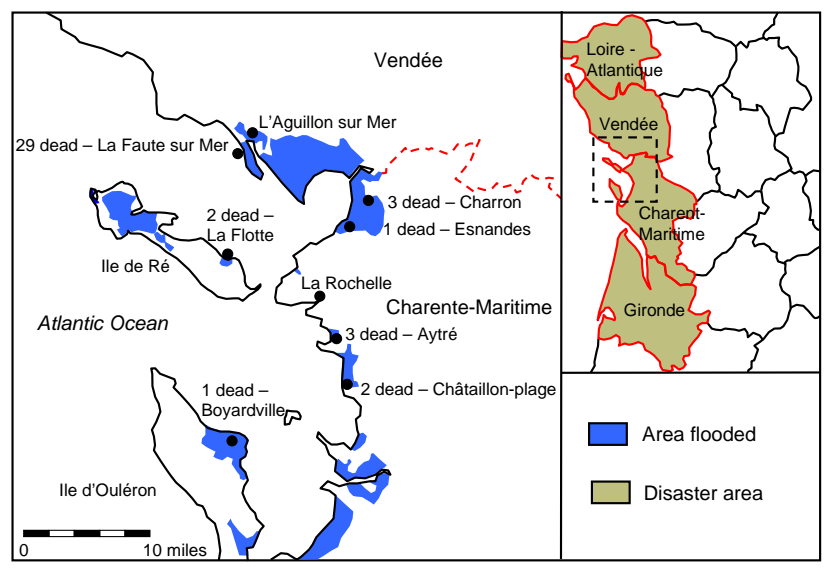

Fig. 3. Area flooded and the loss of life as the result of Xynthia in 2010 .

2010 were in a similar, if not worse, state to those in the UK in 1953. Many of the coastal flood defences that are along the French Atlantic coast date back to the Napoleonic era. Most of the coastal dikes were built originally to protect agricultural land, but with the increasing urbanisation of the Atlantic coast in the past $30 \mathrm{yr}$ their primary purpose has changed. Flood defences that were adequate for agricultural land were not suitable for the protection of new housing developments.

A combination of high tides, low atmospheric pressure coupled with high winds and the failure of coastal flood defences led to widespread flooding along the coast of Vendée and Charente-Maritime and the deaths of 47 people. The inundated area in these two Departments is shown in Fig. 3 (Mercier and Acerra, 2011). It has been estimated that $75 \mathrm{~km}$ of dikes out of a total of $103 \mathrm{~km}$ in Vendée and $120 \mathrm{~km}$ of dikes of the $224 \mathrm{~km}$ in Charente-Maritime needed to be rebuilt or strengthened following the storm. Figure 4 shows an aerial photograph of a breach in a flood defence in Vendée. In some houses in La Faute-sur-Mer, the water level rose to a depth of $2.5 \mathrm{~m}$ within half an hour following the failure of dikes. Some people woke up to find their beds floating $1.5 \mathrm{~m}$ above the floor (Kolen et al., 2010).

Around 10000 people were forced to evacuate their homes on the Atlantic coast. The French government declared a "Catastrophe Naturelle" in four Departments (CharenteMaritime, Deux-Sèvres, Vendée and Vienne). It was reported that more than 9000 French fire fighters and emergency workers backed up by helicopters were deployed on 1 March 2010 to reach residents stranded on rooftops, mostly in Vendée and Charente-Maritime (MEEDDM, 2010). Hundreds of families in coastal regions spent the night in shelters that were set up in schools and public buildings.

Sea defences in France are currently owned by an eclectic range of communities, property owners and individuals, most of whom do not have the necessary financial means

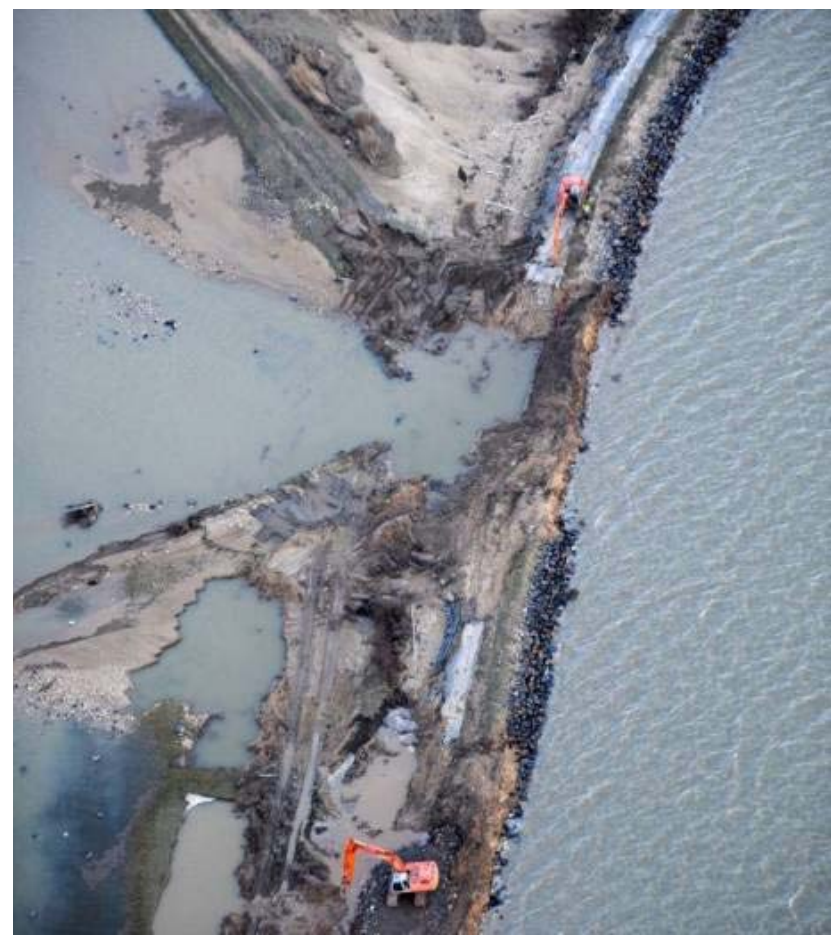

Fig. 4. Aerial view of the damage to a section of coastal flood defences in Vendée.

to maintain them. Approximately $3000 \mathrm{~km}$ of defences are classed as "orphelines" (orphans) by the French Government because their ownership is not known (MEEDDM, 2011).

\section{Exposure to flooding}

In 1953 in east England, it has been estimated by various authors (Baxter, 2005; Jonkman and Kelman, 2005) that approximately 32000 people were exposed to the flood hazard that occurred. The number of fatalities represented approximately $1 \%$ of the exposed population which is in keeping with historical data collated by Jonkman related to fatality rates for coastal surges (Jonkman, 2007). Since 1953 the coastal population on the east coast of England has increased markedly. For example in 1953 the population of Canvey Island was about 12000 people, today it is in excess of 37000 (Lumbroso and Di Mauro, 2008). In other areas, the population has increased by between $30 \%$ and $90 \%$ (Baxter et al., 2002). Suffice to say the number of people living in the east coast floodplain has grown significantly since 1953. On the French Atlantic coast there has been a significant increase in the population over the past $40 \mathrm{yr}$. Figure 5 shows the increase in the total number of houses and the number of houses in the area flooded in 2010 in La Faute-sur-Mer, the worst affected town, based on available land registry and population data. 


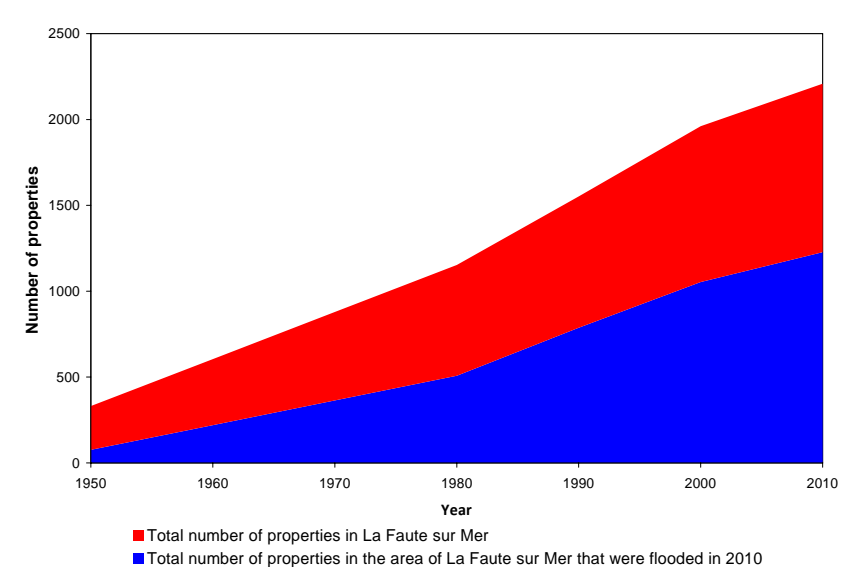

Fig. 5. Growth in the number of properties at La Faute-sur-Mer.

As a result of the increasing urbanisation of the coast, the number of dwellings in the area flooded in 2010 in La Fautesur-Mer increased from 508 in 1980 to 1227 in 2010. Between 1990 and 2000, 266 out of 409 new dwellings constructed in La Faute-sur-Mer were built in flood prone areas. After 2000 the number of buildings built in the 2010 flood zone decreased. However, this decrease in urbanisation was not as a result of any spatial planning land controls or due to an increase in the awareness of the flood risk but as a result of a decrease in the amount of land that was available to develop. In 2010, in the southern part of La Faute-surMer, where the highest water levels were recorded in 2010, (approximately $3 \mathrm{~m}$ ), some houses were still being built on the remaining free parcels of land. It should be noted that many of the new houses built in La Faute-sur-Mer are second homes so it is difficult to assess the occupancy rate when Xynthia hit. However, anecdotal information, collected by the University of Montpellier, indicates that it was around $30 \%$. Another reason for the increase in urban development in coastal areas prone to flooding is peri-urbanization. For example this is the case for the town of La Rochelle in Charente-Maritime. As the town grew and the price of real estate rose, developments began to be constructed in previously undeveloped coastal zones, where land was less expensive.

\section{Vulnerability of the buildings and people}

\subsection{Vulnerability of buildings}

In 1953 in England most of the houses in the communities worst affected by the flooding were constructed using flimsy, wooden frames or were prefabricated bungalow. Of the 307 deaths, at least $216(70 \%)$ occurred in five main clusters: Mablethorpe and Sutton-on-Sea (16 dead), Hunstanton and Snettisham on the Wash (65 dead), Felixstowe and Harwich (over 40 dead), Jaywick (37 dead) and Canvey Island

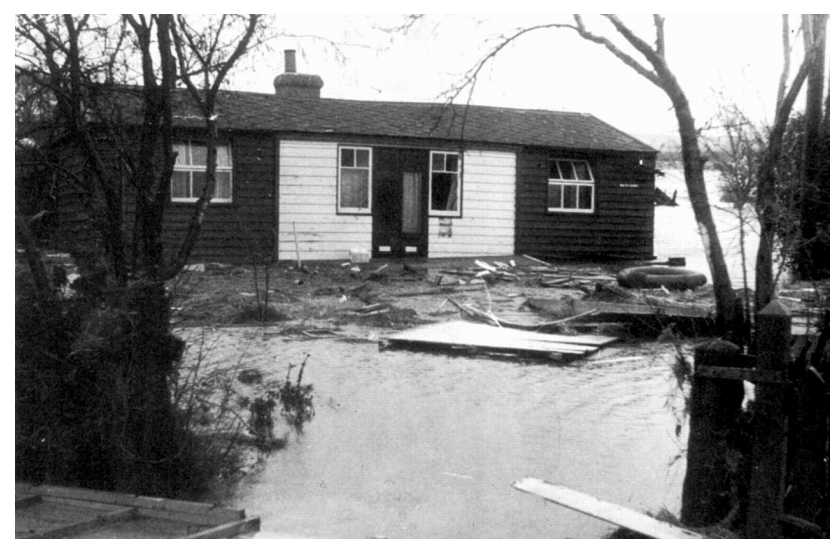

Fig. 6. A typical wooden house that was swept away in the 1953 flood.

(58 dead) (Baxter, 2005). At the time, prefabricated buildings in these communities were commonplace owing to the housing shortage following the Second World War. On Canvey Island, the most vulnerable dwellings were rudimentary, single-storey structures that had been built as cheap retirement homes for workers from the east end of London, for whom the island had become a retirement paradise (Kelman, 2002). Pollard (1978) states that "the Mablethorpe Sutton area of Lincolnshire, the Hunstanton to Lynn area, Jaywick, Canvey Island - were largely seaside shanty-towns consisting mainly of timber bungalows never intended for winter occupation". A view of a typical timber house that was moved more than $300 \mathrm{~m}$ by the flood water in 1953 is shown in Fig. 6. Death tolls were highest in communities with low-quality buildings. For example, 39 fatalities occurred in the Felixstowe on a housing estate comprising prefabricated houses. On Canvey Island, the death toll amounted to 58, with many people surprised in their houses, several of which collapsed, after sea defences failed.

The type of housing stock affected by the Xynthia flood event in 2010 was similar to those affected by the 1953 flood in that 32 of the 41 people who died lived in bungalows. Similar to the 1953 flood, the sea surge occurred at night and many people were surprised sleeping in their homes. The majority of the houses in the inundated area had been fitted with electric shutters and had no access to the roof which turned them into traps, as vertical evacuation to avoid the floodwater became almost impossible. A typical view of bungalows in La Faute-sur-Mer located directly behind flood defences is shown in Fig. 7.

It is important to note that the presence of an upper storey is not necessarily synonymous with security as seven people died in houses with a second floor. In the case of windstorms, the occupants often prefer to sleep on the ground floor because upper storeys are noisy and considered unsafe owing to the wind. In many cases the rescue services had to smash the roof tiles of houses to reach people in bungalows. In 


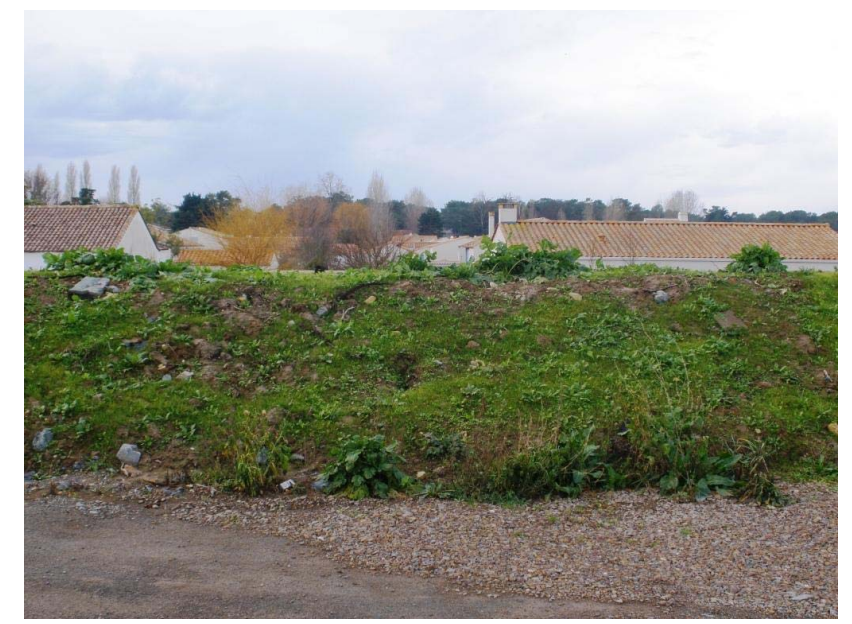

Fig. 7. Single storey houses located behind coastal flood defences in La Faute-sur-Mer.

many communes, local planning regulations prevented construction of an upper floor. The mayor of l'Aiguillon, Maurice Milcent, said "The breach in our sea wall was not the problem! The waters just rose at once, overflowing our communities, built on swamps, in a flood-prone area. The problem has been known since Napoleon's time. According to our regional construction codes, houses had to be "fishermen style" (i.e. bungalows) (Coastal Care, 2011). Table 1 clearly shows the link between the vulnerability of the buildings and the number of deaths.

\subsection{Vulnerability of people}

In the cases of the 1953 and 2010 floods the vulnerability of people also played a large part in the number of deaths that occurred. Pollard noted that for the 1953 flood in England that "the eventual death tolls showed that it was the elderly, who went to bed early and had meagre reserves of energy even if they had time to realise what was happening when the water hit them, who were most vulnerable" (Pollard, 1978). On Canvey Island, 42 out of 58 fatalities were aged over 60. The highest proportional death rate along the whole flooded coast was at Jaywick where $36(5 \%)$ out of 700 residents died, with all the deaths being attributed to drowning. Of these, $82 \%$ of victims were aged $60 \mathrm{yr}$ and over, and in the youngest age groups, under 44 , the dead comprised two people who were described as disabled, one woman in an advanced state of pregnancy, two adults who died trying to save others and one child aged 11 (Baxter, 2005; Grieve, 1959). In south Lynn, all 14 fatalities were over 60. Deaths were not necessarily caused by drowning. Of the 41 post mortems carried out at Canvey Island, 14 people died of other causes than drowning, such as shock and heart attack (Jonkman and Kelman, 2005). Figure 8 shows the ages of the people that died at Canvey Island and Jaywick.

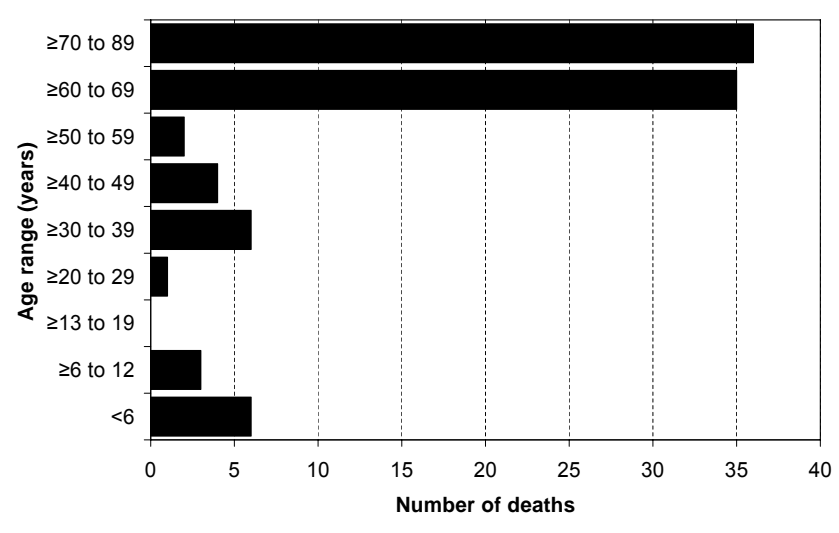

Fig. 8. Age of the people who died in the 1953 floods at Canvey Island and Jaywick.

In the Departments of Charente-Maritime and Vendée there were 41 deaths related to the 2010 coastal surge of which 29 occurred in the town of La Faute-sur-Mer in Vendée and 12 in the Department of Charente-Maritime. In La Fautesur-Mer, 28 out of the 29 fatalities occurred in an area measuring 3 ha that became known as the "bowl of death" by the media and political authorities. Figure 9 shows the age and sex of people who died in the 2010 floods in France. It is important to note that no official data was collated by the French Government on the fatalities. The data in this paper were collected by researchers from the University of Montpellier who, working with local stakeholders such as the fire service, compiled the information in the six months after the floods occurred.

For the 2010 event in France, $71 \%$ of the people who died were aged over 60 . The median age of the victims was 75 , which is high taking into account that the median age of the communities where fatalities occurred is 52 and that the median age of the French population is $38 \mathrm{yr}$ old (INSEE, 2007). In the town of La Faute-sur-Mer, people aged over 74 comprised only about $16 \%$ of the total population. However, it should be noted that the flooding occurred during the school holidays and no information was available on the "non-resident" population who may have been on holiday at the time. In La Faute-sur-Mer, it was possible to determine from land registry datasets that at least 20 out of 29 victims were local residents. Figure 9 shows that there were no victims in the age range 20 to 40 . The five fatalities aged less than 20 were children on holiday with their parents or grandparents. The age distribution of the victims is very similar to the 1953 flood where there was also an over-representation of elderly people.

\section{The response to the 1953 and 2010 flood events}

Johnson et al. hypothesise that national flood events create a "window of opportunity" for increasing the rate at which 
Table 1. Number of deaths and the types of building they occurred in during Xynthia.

\begin{tabular}{lclll}
\hline Type of building & Bungalow & $\begin{array}{l}\text { Bungalow with one upper } \\
\text { room acting as a refuge }\end{array}$ & Houses with an upper floor & Others (e.g. caravans) \\
\hline Number of deaths & 32 & 4 & 3 & 2 \\
\hline
\end{tabular}

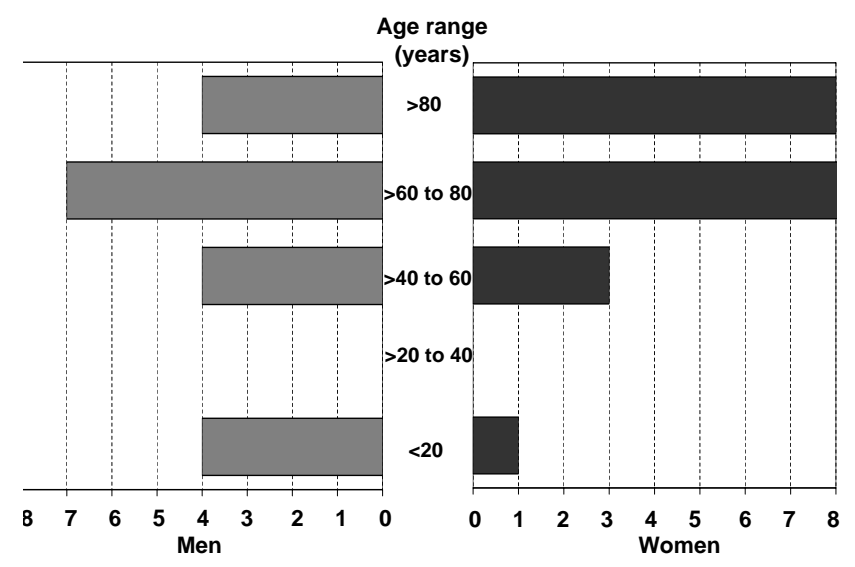

Fig. 9. Age and sex of the people who died in the 2010 coastal floods caused by Xynthia.

flood risk management policy changes or for fundamental changes in policy. A flood is defined as a "crisis" if its scale and its impacts are of more than regional significance, and recognised by the national Government as such (Johnson et al., 2002). Policy change acceleration as the consequence of a major flood emergency is not necessarily based on the development of new ideas but can help to promote existing ideas that are already the subject of widespread discourse within the framework of an existing flood risk management policy (Penning-Rowsell et al., 2006). The East Coast flood of 1953 and the "tempête" Xynthia events were certainly exceptional floods in recent history, both in their nature, severity and impact. The responses to the two floods are detailed below.

The 1953 flood in England led to the following accelerated policy initiatives and responses:

1. The development of a Storm Tide Warning System for the east coast of England.

2. The setting of new design standards for coastal flood defences at the 1953 level.

3. Investment in improving and strengthening coastal flood infrastructure.

4. A substantial new research effort into coastal processes, protection and forecasting.

In 1953 in the UK there was no national flood warning service or coordination. Flood defence was organised by a number of River Boards. They had emergency plans but they were not linked up on a national basis. Emergency plans were hampered by communications failures in most locations (Environment Agency, 2009a). One of the British Government's primary concerns after the 1953 flood was to set up a coastal flood warning system. The 1953 flood led directly to the creation of the Storm Tide Warning Service, a national flood warning organisation, created to improve the accuracy and efficiency of coastal surge warnings to the public as well as the authorities. Just ten days after the flood, the Government announced emergency arrangements as a "stop-gap" before a more permanent system could be devised (PenningRowsell et al., 2006).

Although at the time of the 1953 flood a rudimentary surge flood warning system was in place for London (Waverley, 1954), little thought had been given to a more accurate and far reaching system covering the east coast of England. This was partly because at the time storm, surges in the North Sea were poorly understood and there was no appropriate medium for communicating the warnings as the fledging, national radio system was not considered to be appropriate (Penning-Rowsell, 2006; Waverley, 1954). Soon after 1953 a network of tidal gauges was installed around the British Isles' coastline to provide accurate water height measurements and connect weather forecasts with tidal movements. This network can now provide warnings up to $12 \mathrm{~h}$ in advance of an extreme storm surge. A system of sirens originally set up for civil defence purposes along the east coast was expanded and used to provide warnings to communities of any extreme floods following the 1953 event. The minutes of the Waverley Committee set up to investigate the 1953 flood indicate that many of the policy changes were driven by Proudman and Steers, a University of Liverpool oceanographer and a University of Cambridge Geographer, respectively.

The 1953 flood in England was a "wake-up call". A year after the disaster, the government claimed "12 years' work had been completed in 12 months" to sure up Britain's coastal defences, the Manchester Guardian reported. £20 million (approximately $£ 350$ million in today’s terms) had been spent on reinforcing "thousands of miles of sea and tidal river defences. Along large parts of the East Coast ... the wall had been raised by a minimum of three feet [approximately one metre] and had been greatly increased in width so that the scouring effect of wave action would be virtually impossible" (Sturcke, 2007). Hansard, the printed transcripts of parliamentary debates in the UK, shows that the issue of design 
standards for flood defences had been debated since the Great Flood of 1947 that were the most catastrophic river floods for at least $200 \mathrm{yr}$ in the UK (RMS, 2007). It would appear that the use of the 1953 level did not come about as the result of a scientific debate but because it would have been politically impossible to suggest a lower level (Johnson et al., 2002). The 1953 flood thus resulted in evidence-based standards of coastal flood defences with this level being the maximum level provided unless benefits gained by having higher defences could be adequately demonstrated.

Although central London had escaped the flood in 1953, the vulnerability of the city was highlighted to politicians. If the tidal surge had reached central London, the death toll and damage could have been significant. Over a million people would have been in danger. The probable damage to London's infrastructure including water and sewage system, underground, gas and phone lines would have disrupted life in the capital for months and been costly to repair.

The 1953 flood acted as a catalyst for Britain's largest ever coastal defence improvement programme. In the years following the 1953 flood, coastal defences were raised by up to two metres in areas where the risk (i.e. the number of people) was highest (RMS, 2003). In many places the coastal defences were improved so that they could protect against storm surges with an annual probability of up to 1 in $1000 \mathrm{yr}$. After the floods, an enquiry was set up to work out ways of protecting London in the future. As the old system of embankments was clearly no longer adequate, the enquiry recommended the construction of a flood barrier across the Thames.

The fourth aspect of the 1953 flood was the increase in the coastal research effort following the flood. After 1953 the Proudman Laboratory at Liverpool University developed the use of approximate statistical methods for the east coast of England and their continuing research led to the world's first storm-surge prediction scheme based on a numerical model being set up in 1978 and which has been upgraded ever since (Jones, 1999). Other areas of coastal research that commenced included long-term sea-level change (Jones, 1999).

Similar to the 1953 floods in Britain, the floods caused by Xynthia have acted as a catalyst for change in France. Xynthia caused the worst ever coastal flooding in terms of mortalities recorded to date. An historical study of coastal surges by Garnier and Surville (2010) indicates that there has been no previous coastal surge in France with such a high death toll (Garnier and Surville, 2010). The French Government declared the 2010 floods a "natural catastrophe" so it will be interesting to note if they also have the same longterm impact that the 1953 flood had on flood risk management policy in the England. One immediate response to the Xynthia flood was that the French Government announced on 8 April 2010 that it had decided to destroy 1510 houses in the affected areas of which 823 were in the Vendée and 595 were in Charente-Maritime. The government promised to fully compensate all home-owners, based on the value of the real estate prior to the storm with the ministry of finance stating that they would pay $€ 250000$ per house (MEEDDM, 2010). To date in Vendée of the 823 homes designated by the French state to be destroyed, nearly 700 homeowners have accepted the compensation terms by the state with demolition taking place in March 2011. There remain 79 people who have decided to take the matter further legally (http://Lafautesurmer.net, 2011).

In February 2011 the French Government produced a document called "Plan submersions rapides: Submersions marines, crues soudaines et ruptures de digues" (Rapid inundation plan: coastal floods, flash floods and dike failures) (MEEDM, 2011). This plan details the policy response brought about not only as a result of Xynthia in February 2010, but also severe flash flooding in the Var Department in southern France in June 2010 that led to the deaths of 25 people. There are four priority areas detailed in the plan as follows:

1. Control of urban developments in areas at risk of flooding.

2. Improvements in coastal forecasting and warning.

3. Strengthening of flood defences.

4. Developing a "culture of risk awareness".

In terms of the control of urban development in flood hazard zones, the French Government has stated that there will be a concerted effort to complete "Plans de Prévention des Risques Littoraux" (PPRL), i.e. coastal flood risks plans. The goal is that within three years, 242 new coastal communities will be covered by a risk prevention plan and that the existing plans of a further 68 communes will also be revised. The government will introduce a law meaning that the construction of new coastal flood defences to allow new areas adjacent to the coast to be developed will be prohibited. By the end of 2011, the French Government will also have a technical reference document in place to assist professionals in providing flood risk management solutions.

When Xynthia occurred, although an effective fluvial flood forecasting system existed this was not the case for the French coasts. During a parliamentary inquiry in 2010, a representative of the Service Hydrographique et Océanographique de la Marine (SHOM) (Hydrographic and Oceanographic Service) stated that the two coastal level measuring stations covering this part of the French coast currently did not have the ability to read real-time data and that they often broke down (SENAT, 2010). The monitoring stations do not currently provide an effective way of forecasting tidal surges. There are currently only 17 tidal gauges on the French coast that can provide real time sea level information. A programme of upgrading tidal gauges began in 2009 as part of a project related to providing tsunami warnings (SENAT, 2010). The French Government has stated that they 
will put in place a programme to improve the real time monitoring of coastal surges and warnings for the areas with the highest risk along the French coast.

One of the many criticisms following Xynthia was that no warning was given concerning the possibility of coastal flooding. The French Government has stated that by the end of 2011, Météo France will be in a position to deliver a specific weather warning related to "coastal flooding". For each coastal Department Météo France will provide a colourcoded warning (i.e. green, orange or red) based on the forecast sea level and wave heights.

In France the coastal defences in 2010 were generally in a "poor" state of repair (Dupray et al, 2010). A French Act of law passed in 1807 , related to the draining of the marshlands, places the responsibility for the operation and maintenance of flood defence dikes on their owners. In France the state is responsible for checking that the owner is fulfilling their duties. More recent laws also state that the owners of dikes need to ascertain the risk that they pose to people and infrastructure (MEEDDM, 2010). Although the legal framework was in place to manage the defences, in reality the practice was very different owing to complex ownership structures involving a range of stakeholders (e.g. the state, local authorities, private individuals). In Charente-Maritime, only $35 \%$ of flood defence owners could be identified. In general for areas hit by Xynthia, the inventory of flood defence assets was poor. It is also important to note that other infrastructure such as road or railway embankments, which in some cases act as flood defences, have no clear legal status.

Since the flooding took place, some $€ 43$ million has been spent in the Departments of Charente-Maritime and Vendée on repairing the damage to flood defences caused by Xynthia. In February 2011 the French Government made a commitment to make available $€ 500$ million to reinforce 1,200 $\mathrm{km}$ of flood defences between 2011 and 2016. A list of flood defences where the risk of failure is greatest is to be prioritised by the end of 2011. The safety of hydraulic structures (i.e. dams and flood defences) will fall under the Direction Régionale de l'Environnement, de l'Aménagement et du Logement (DREAL) (the Regional Directorate of Environment Planning and Housing). An additional 50 posts will be created to assist with this task. In 2012 the French Government will investigate the possibility of introducing a legal mechanism via which local taxes collected at an appropriate scale can be raised to finance the maintenance of flood defences.

It was recognised by the French Government that there is a need to improve people's awareness of floods, especially on the coast. It was evident that many senior civil servants and communities in the Departments affected did not fully understand the nature of the flood risk. This is illustrated by an interview with Beatrice Lagarde, a high ranking official in Vendée who, after the flood, spoke of the impossibility of evacuating 400000 people (approximately two-thirds of the population of Vendée) during a storm, when actually the evacuation of a few thousand people would have saved about
30 lives (Kolen et al., 2010). In France local emergency plans, known as Plan Communal de Sauvegarde (PCS) aim to prepare communities to cope with emergencies. From 2011 onwards, it will be a requirement to prepare a PCS when Plans de Prévention des Risques Littoraux (PPRL) (Coastal flood risk plans) are produced. From 2011 onwards PPRLs will have to take into account increases in sea level as a result of climate change.

\section{Discussion}

The 1953 east coast floods in England and the "tempête" Xynthia in France both resulted in the acceleration of flood risk management policies. However, there still remain several questions as to the "legacy" of the 1953 flood in Britain and whether the changes in flood risk management proposed by the French Government following Xynthia are far reaching enough.

In England and Wales, the responsibility for flood risk management including: fluvial and coastal flood forecasting and warning; operation and maintenance of most fluvial and coastal flood defences; raising awareness of and communicating flood risk is the responsibility of one organisation the Environment Agency. In France the responsibility for fluvial and coastal flood risk management is fragmented. A national flood forecasting service, "Service Central d'Hydrométéorologie et d'Appui à la Prévision des Inondations" (SCHAPI) with 22 regional offices was sent up in 2003 (MEEDDM, 2010). Unlike the Environment Agency, SCHAPI only forecasts fluvial flood flows and levels and it does not disseminate warnings to a wide variety of stakeholders in a number of different forms (e.g. in different languages and media) as is the case in England and Wales. The monitoring of coastal levels in France is undertaken by the Service Hydrographique et Océanographique de la Marine (SHOM); however, currently they do not provide a coastal surge forecasting service. The assessment of the probability of floods and the risk they pose is the responsibility of the Direction Régionale de l'Environnement, de l'Aménagement et du Logement (DREAL) in France. This is a separate organisation from SCHAPI and SHOM and one that is not responsible for the management of flood defence assets. The fragmented manner in which flood risk management from a variety of sources (e.g. rivers, coasts, pluvial) is organised in France is in stark contrast to the more unified and holistic approach of the Environment Agency.

The organisational differences discussed above are partly reflected in France's approach to the management of coastal flood risks before Xynthia struck. In France until recently, the risks posed by coastal flooding were perceived to be relatively low by stakeholders. Historians such as Coeur argue that the focus has generally been on fluvial floods because the major cities and the political centres (i.e. Paris, Lyon, 
the Tourain region) are adjacent or traversed by France's largest rivers and have experienced the most extreme floods (i.e. River Rhone 1856 in Lyon, River Seine flood in Paris, 1910) (Coeur, 2002; Jackson, 2010). Although there have been coastal floods in the past in France (Garnier and Surville, 2010), owing to the centralized nature of the French Government system and the fact that the main centres of political influence are subject to fluvial flooding, flood prevention in France has focused mainly on major rivers rather than the coastal flood risk.

Garnier and Surville (2010) carried out a study of historical storm surges on the French Atlantic Coast (Garnier and Surville, 2010). In the past, local populations were well aware of the risks that coastal storm surges posed mainly because people where living in closer contact with the sea. In Charente-Maritime, sea surges were called "vimers" in the local dialect (Garnier and Surville, 2010). Garnier and Surville (2010) relate the example of the sea surge that hit Noirmoutier Island on the coast of Vendée on the night of 13 and 14 March 1937. The situation was similar to Xynthia with strong winds, a spring tide and the surge occurring in the middle of the night. However, no deaths at coastal habitations were reported. Garnier and Surville explain the absence of deaths in the 1937 surge by the fact that local awareness of the risk was high at that time and that in some areas a warning was given by an alarm bell that led to the population being prepared for the flood. The main reason for the difference in death tolls between 1937 and 2010 was combination of increasing coastal urbanization behind often weak flood defences coupled with a decrease in the levels of flood risk awareness as a result of people moving from inland areas to the coast over the past $30 \mathrm{yr}$.

In the recent past the French state has tended to withdraw funding for coastal flood defences. As a consequence, in some parts of Vendée maintenance had been left to local authorities who had to maintain $21 \mathrm{~km}$ of coastal defences with an annual budget of only $€ 70000$ (MEEDDM, 2010). This is approximately $€ 3300$ per kilometre of defence per year. This contrasts with annual budget in England and Wales of about $€ 8200$ per kilometre of defence (Environment Agency, $2009 b, c)$. Anziani (2010) summarised the situation "it is imperative to change the complex and uncontrolled system of the management of flood defence dikes. Too many organisations are involved in their management. Despite increased regulatory control since December 2006 flood defence dikes are poorly maintained... it is essential that where maintenance responsibilities for levees are not defined that control is taken by a competent authority". The 1953 floods led to this level being used as a "benchmark" for coastal flood defence levels in Britain. Following Xynthia there still appears to be no national policy in France as to what the levels of protection coastal flood defences should afford to endangered communities and how this should be assessed. In England in 1953, the first reaction to the flood was to strengthen the coastal flood defences. In France the initial reaction was to state that houses in the "zone noires", (the areas perceived to be at the highest risk), were to be knocked down.

Throughout England and Wales, there is some $38000 \mathrm{~km}$ of flood defences and 46000 flood defence structures (NAO, 2007) managed and maintained by one organisation, the Environment Agency. In France there is no national technical guidance on flood defence maintenance (Dupray et al., 2010). The other key difference in England and Wales is that the Environment Agency has established a rigorous system for classifying, recording and monitoring the condition of flood defence assets, including a database containing comprehensive information on the state of flood defences (NAO, 2007) that allows resources to maintain and operate them to be allocated systematically rather than on an ad hoc basis, as appears to be the case in France.

During the 1953 flood, questions were raised, in parliament and elsewhere, concerning the adequacy of the system of finance and responsibility for flood defence and coastal erosion. The significance of which is highlighted by the inclusion of this issue as one of the four Terms of Reference of the Waverley Committee: "to review the lessons to be learned from the disaster and the administrative and financial responsibilities of the various bodies concerned in providing and maintaining the sea defences and replacing them in the event of damage; and to make recommendations" (Waverley, 1954). This ability of local authorities to raise the necessary finance for flood and coastal flood defence works was an important issue in the Waverley Committee considerations. There has been consideration of this also in France but it appears unlikely as to whether small communities like La Faute-sur-Mer, with a permanent population of around one thousand people, would have the necessary means available to raise sufficient finance to maintain coastal defences.

The Government in Britain has recently suggested that it wants local communities to partly fund new flood defences. This would mean that communities which can afford to pay towards mitigation measures would be given a higher priority in terms of receiving Government funding than communities that cannot contribute. However, similar to France it has not been explained how a policy like this would not discriminate against the poor communities that cannot afford to contribute to their protection (Guardian, 2010). This view was expressed by the British Property Federation who in a recent paper on the funding of flood defences stated: "Following the 2007 floods, there have been examples of local community funding of flood defence schemes. Often the decisions for such schemes are not based on scientific analysis of cost/benefit but rather more simply as a reaction to a flood event and a resulting desire to provide defences against a repeat event irrespective of any statistical appraisal of the likelihood of future events. There is no problem with this in principle although it is more likely to be feasible in affluent communities and in areas of high property values, but it is not something upon which the government should rely as it is outside of the recognised justification process based on 


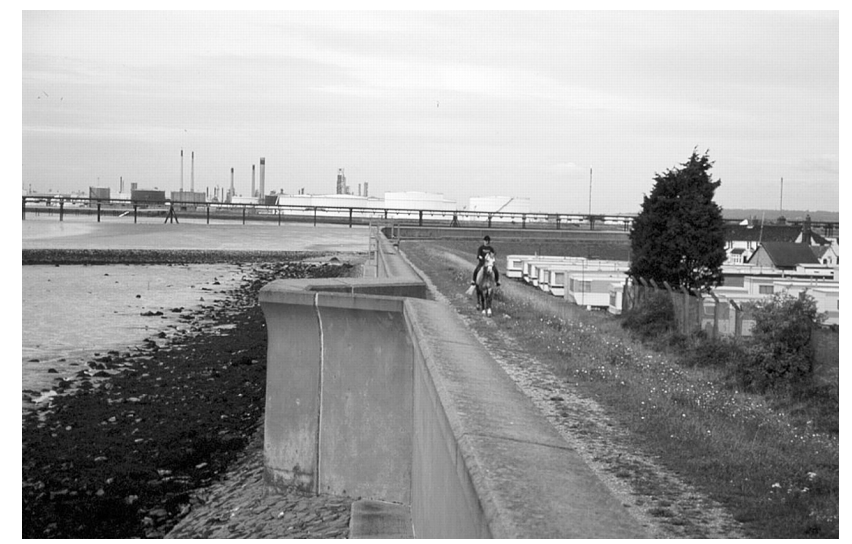

Fig. 10. Improved flood defences built to protect Canvey Island following the 1953 flood.

cost/benefit appraisal which is essential to fair decisions being made on the distribution of government funding" (British Property Federation, 2011).

In 1953 there was little in the way of development planning regulations with respect to coastal flooding. As a consequence, many houses were constructed in areas at risk of flooding. In France it is estimated that currently an area of approximately 3.7 million $\mathrm{m}^{2}$ per year is built on along the coast. It is French mayors who are responsible for granting building permits. Although there are often flood hazard maps for communes that show areas susceptible to flooding, these are often ignored by mayors. Since the Decentralization Act of 1982, the French Government no longer checks decisions made by local authorities before they are finalized. This check was replaced by a legal verification afterwards by prefects and courts (Le Figaro, 2010b).

The mayor of Charron, a commune badly hit by Xynthia, publically admitted that he was guilty of violating the spatial planning act (Kolen et al., 2010). The mayor of La Fautesur-Mer claimed that he was not aware of the dangers, but a reaction in Le Monde stated that the prefect had formally warned the mayor in writing in 2001, 2006 and 2008 about the flood danger from the sea and the lack of adequate protection against coastal flooding (Kolen et al., 2010).

Since 1953 flood defences in the UK have been raised and strengthened. Typical examples of improved flood defences that provide a 1 in $1000 \mathrm{yr}$ level of protection to Canvey Island in the Thames Estuary are shown in Fig. 10. Paradoxically, the strengthened defences on the east coast of England may have provided the potential for further human disaster rather than eliminated it, despite the confidence placed by the Waverley Committee in a flood warning system. Baxter et al. (2002) note that between 1951 and 1991, the UK's population increased by $12 \%$ but the population of many coastal areas in eastern England increased by between $17 \%$ and $92 \%$. Between 2001 and 2021, the coastal counties from Essex on the Thames Estuary to Humberside on the Humber

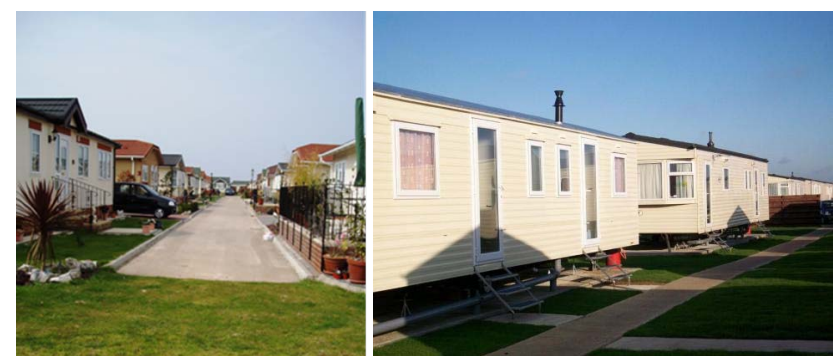

Fig. 11. Examples of housing vulnerable to floods on Canvey Island.

Estuary are expected to gain 322000 new households, $10 \%$ of England's projected need (ODPM, 2000). Recent research has shown that a reduction in flood risk as a result of mitigation measures can be a major catalyst for local regeneration and/or development on the floodplain where significant flood risks have been mitigated (DEFRA, 2008b).

Canvey Island proves an interesting case. The population of the island has risen from an estimated 12000 in 1953 to over 37000 today (Baxter, 2005; Lumbroso and Di Mauro, 2008). Access to Canvey Island is currently only possible by two roads both of which are connected to the same roundabout. Any disruption to these routes would hamper evacuation and severely limit access. A number of properties are vulnerable to flooding with $30 \%$ of the housing stock being bungalows and $45 \%$ of flats being located on the ground floor (Kelman, 2002). In the past decade, many hundreds of houses that would be extremely vulnerable during a flood have been constructed, as shown in Fig. 11.

Concerns regarding emergency planning have been raised by local communities who state that "major issues" include "the lack of safe havens, lack of a fit for purpose emergency plan and of course the problems associated with evacuation amongst others. The Council has to date not provided evidence that it can confidently provide a robust emergency flood response strategy for Canvey Island, which would be cut off from the mainland for some considerable time during extreme flood conditions" (CGC, 2009a). The risk posed by flooding and the possibility of an extreme flood inundating the island does not appear to have been planned for, and this is despite the fact that urbanisation of Canvey Island, including caravans and mobile homes, has increased the vulnerability of its residents (CGC, 2009b).

\section{Conclusions and recommendations}

There is a striking similarity between the coastal events of 1953 in England and those of 2010 in France. In both 1953 and 2010, the various government organisations found it difficult to work together to assess the seriousness of the threat and to warn the population in time of the impending flood threat. It also turned out that the protection offered by the flood defences and their condition was often unknown. The 
Table 2. A summary of the different aspects of flood risk management and the organisations responsible for carrying these out in England and Wales, and France.

\begin{tabular}{lll}
\hline $\begin{array}{l}\text { Aspect of flood risk } \\
\text { management }\end{array}$ & England and Wales & France \\
\hline Fluvial flood forecasting & Environment Agency & $\begin{array}{l}\text { Service Central d'Hydrométéorologie et d'Appui } \\
\text { à la Prévision des Inondations }\end{array}$ \\
\hline Coastal flood forecasting & Environment Agency & $\begin{array}{l}\text { Service Hydrographique et Océanographique de la } \\
\text { Marine (SHOM) - SHOM monitors coastal water } \\
\text { levels but does not currently provide forecasts }\end{array}$ \\
\hline $\begin{array}{l}\text { Flood warning } \\
\begin{array}{l}\text { Assessment of flood hazard } \\
\text { and risk }\end{array}\end{array}$ & Environment Agency & $\begin{array}{l}\text { Mayors of the estimated 10 000 } \\
\text { communes affected by floods }\end{array}$ \\
\hline $\begin{array}{l}\text { Maintenance of fluvial and } \\
\text { coastal flood defences and } \\
\text { structures }\end{array}$ & $\begin{array}{l}\text { Environment Agency and in } \\
\text { some cases local authorities and } \\
\text { ports }\end{array}$ & $\begin{array}{l}\text { Direction Régionale de l'Environnement, de } \\
\text { l'Aménagement et du Logement (DREAL) }\end{array}$ \\
\hline $\begin{array}{l}\text { Emergency planning } \\
\text { for floods }\end{array}$ & $\begin{array}{l}\text { Environment Agency in } \\
\text { conjunction with emergency of organisations } \\
\text { responders and other key stake- } \\
\text { holders }\end{array}$ & $\begin{array}{l}\text { Mayors of the estimated 10 000 communes } \\
\text { affected by floods }\end{array}$ \\
$\begin{array}{l}\text { Guidance on the construc- } \\
\text { tion of new developments in } \\
\text { areas at risk of flooding }\end{array}$ & \begin{tabular}{l} 
Environment Agency \\
\hline
\end{tabular} & $\begin{array}{l}\text { Mayors of the estimated 10 000 communes } \\
\text { affected by floods }\end{array}$ \\
\hline
\end{tabular}

most important part of emergency management was missing in that there was no coastal surge forecast and warning system in place. As this paper points out, both events led to an acceleration of flood risk management policy. There are a number of lessons that can be learnt from the two events and many of the changes in flood risk policy in England and Wales that occurred after 1953 are relevant in France. There are a number of recommendations that need to be implemented in both countries to prevent future loss of life as a result of coastal flooding. Table 2 summarises the various aspects of flood risk management in the two countries and the organisations responsible for carrying these out.

In France the organisational picture is complex and fragmented. In contrast, in England and Wales, almost all aspects of flood risk management fall under the responsibility of one body, the Environment Agency. In France there are divisions of responsibility with respect to the issuing of forecasts, warnings and the operation and maintenance of important flood defence infrastructure. There has been a limited attempt following Xynthia by the French Government to rectify some of these organisational issues; however, there is still much work to be done to make flood risk management in France more "joined-up" and to avoid the issues caused by a lack of integration between the different key stakeholders.

In France there is still a need to produce risk based standards in terms of levels of protection for flood defences, as currently, the approach to the level of protection offered to communities still appears to be ad hoc. There is a requirement to have a more transparent approach as to how decisions are made concerning the level of protection afforded to coastal communities.

The lack of a shared responsibility and solidarity is a fundamental problem for the management and maintenance of flood defences in France. Although the plans outlined by the French Government go some way to address these, there is still a need for a more holistic approach to the management of flood defence infrastructure.

The creation of flood risk zoning in France should assist in reducing the probability of future damage and casualties. However, it is only effective if the rules are clear and applied in a consistent manner at a national level. To implement this requires the setting up of a national agency.

In recent years there has been an increase in the number of communities exposed to coastal floods mainly as a result of a "relaxed" application of spatial planning regulations in France. In England and Wales, the number of people living in coastal flood risk zones in vulnerable houses has also increased. However, since 2007 there has been a more centralised and organised approach to planning new developments with respect to floods with the Environment Agency now having the right to call for a Public Enquiry should they disagree with a local authority's planning decision regarding 
a new development in a flood risk area. France could benefit from a more centralised approach to development planning for floods. In the past, the effectiveness of French legislation regarding developments in flood zones has suffered from slow implementation, ways to circumvent it, and controversial planning decisions made at a local level. It is important that lessons are learnt from the implementation of previous legislation to avoid the same mistakes being repeated.

A five yearly inspection programme for flood defences coordinated by a centralised agency in France needs to be set up similar to that which exists in England and Wales. Management of flood defences requires strong, independent, democratic organizations. Costs and benefits must be proportional for all interested parties to reduce the risk of overdue maintenance.

Flood warnings in France should be made understandable for a range of stakeholders including emergency managers, the police, the fire service and the general public. Warnings in France should be issued in a number of forms and via a number of different media as is the case in the UK. This would allow stakeholders to be more self-reliant as they can decide for themselves what actions they want to take. Currently in France there is no centralised flood warning system and many of the warnings that are issued are too technical.

The fact that flood defences might fail in various locations and that these are difficult to predict should be considered in emergency plans and disaster relief in both countries. Decisions concerning emergency management, both before and during a crisis, must be based on various scenarios, with information about the risks and consequences. In England there are still communities who live behind flood defences in relatively vulnerable housing who often do not have a good perception of the actual flood risk.

To conclude, France needs to draw on the lessons learnt in England following the 1953 floods shifting the responsibility for flood risk management from a number of disparate, often technically oriented organisations to assist in addressing fully the problems of flood risk management in a holistic manner. In both countries there needs to be an understanding of the needs and roles of a myriad of stakeholders (such as local councils, the fire service, police force and community members) and of how to work with them effectively across the whole flood risk management cycle, including emergency planning.

Acknowledgements. We would like to acknowledge the support of the Royal Academy of Engineers (RAEng) who provided a Global Research award to Darren Lumbroso to assist him in undertaking some of this work. We wish to extend our thanks to the RAEng for their support. We also wish to thank the researchers from Unité Mixte de Recherche, Gouvernance, Risque, Environnement, Développement (GRED), Institut de Recherche pour le Développement (IRD), Université Paul-Valéry Montpellier III for the valuable work they undertook in collecting the data used in this paper, as well as the comments provided by the two reviewers.
Edited by: M.-C. Llasat

Reviewed by: B. Jonkman and D. Mercier

\section{References}

Anziani, M. A.: Rapport d'information fait au nom de la mission commune d'information sur les conséquences de la tempête Xynthia, Tome I : Rapport, No. 647, Sénat Session Extraordinaire De 2009-2010, 2010.

Baxter, P. J.: 1953: a summary of the human disaster 1 February - The east coast Big Flood, 31 January, Phil. Trans. R. Soc. A., 363, 1293-1312, doi:10.1098/rsta.2005.1569, 2005.

Baxter, P. J., Moller, I., Spencer, T., Spence, R. J., and Tapsell, S.: Flooding and climate change, In Health effects of climate change in the UK, 152-192, London: Department of Health, 2001.

British Property Federation: A British Property Federation response to: Future funding for flood and coastal erosion risk management: Consultation on the future Capital Grant-In-Aid allocation process in England, 2011.

Canvey Island Greenbelt Campaign (CGC): Submission on the PPS25: Development and flood risk sequential test and exception test update, September 2009, available at: http://www.canveygb. co.uk/data/SeqandExcept.pdf, last access: 1 March 2011, 2009a.

Canvey Island Greenbelt Campaign (CGC): Presentation to Castle Point Borough Council's special policy and development group August 2009 Canvey green belt campaign Available at: http://www.canveygb.co.uk/data/CGBC_Presentation. pdf, last access: 1 March 2011, 2009 b.

Coastal Care: Coastal Care web site, http://coastalcare.org, last access: 1 March 2011, 2011.

Cooling, L. F. and Marsland, A.: Soil mechanics studies of failures in the sea defence banks of Essex and Kent Conference on the North Sea Floods of 31 January/1 February, 1953: A collection of papers presented at the Institution in December 1953. London: Institution of Civil Engineers, 58-73, 1954.

Cœur, D.: Aux origines du concept modern de risque naturel en France, Le cas des inondations fluviales (XVIIe-XIXe s.), in: Histoire et mémoire des risques naturels CNRS MSH Grenoble, edited by: Favier R. and Granet-Abisset A. M., 117-137, 2002.

Department for Environment, Food and Rural Affairs (DEFRA): Flood and coastal defence appraisal guidance Social appraisal - Supplementary note to operating authorities - Assessing and valuing the risk to life from flooding for use in appraisal of risk management measures, May 2008, http://archive.defra.gov.uk/environment/flooding/ documents/policy/guidance/fcdpag/risktopeople.pdf, last access: 6 June 2011, 2008a.

Department for Environment, Food and Rural Affairs (DEFRA): Who benefits from flood management policies? R\&D Technical Report FD2606/TR, http://randd.defra.gov.uk/Document.aspx? Document=fd2606_7682_TRP.pdf, last access: 6 June 2011, 2008 b.

Dupray, S., Tourment, R., Pohl, R., Schelfhout, H., Williamson, T., Gamst, K., and Sharp, M.: International levee handbook - Scoping report, http://www.ciria.org/service/Home/AM/ ContentManagerNet/ContentDisplay.aspx?Section=Home $\backslash$ \&ContentID=17434, last access: 5 January 2011, 2010.

Environment Agency: 1953 floods - key facts, http://www. environment-agency.gov.uk/homeandleisure/floods/38317.aspx, 
last access: 5 January 2011, 2009a.

Environment Agency: Flooding in England: A national assessment of flood risk, 2009b.

Environment Agency: Flooding in Wales: A national assessment of flood risk, 2009c.

Garnier, E. and Surville, F.: La tempête Xynthia face à l'histoire Submersions et tsunamis sur les littoraux français du Moyen Age à nos jours, ISBN 978-2-36199-009-1, 2010.

Grieve, H.: The great tide, Chelmsford, County Council of Essex, 1959.

Guardian newspaper: Flood defence spending: a crack in the dam?, http://www.guardian.co.uk/environment/ damian-carrington-blog/2010/dec/23/flooding-defence-budget, last access: 3 March 2011, 2010.

Institut National de la Statistique et des Etudes Economiques (INSEE): Résultats du recensement de la population - 2007, 2007.

Jackson, J. H.: Paris under water: How the city of light survived the Great Flood of 1910, New York, Palgrave Macmillan, 2010.

Johnson, C., Tunstall, S., and Penning-Rowsell, E.: Crises as catalysts for adaptation: Human response to major floods, Research report, ESRC Environment and human behaviour new opportunities programme, Award No.: RES-221-25-0037, Flood Hazard Research Centre, Publication No. 511, 2002.

Jones, E.: From astronomy to oceanography - A brief history of Bidston observatory, Ocean Challenge, 9(1), 29-35, 1999.

Jonkman, S. N. and Kelman, I. K.: Deaths during the 1953 North Sea storm surge pp. 749-758 in Proceedings of the Solutions to Coastal Disasters Conference, American Society for Civil Engineers (ASCE), Charleston, South Carolina, 8-11 May 2005, 2005.

Jonkman, S. N.: Loss of life estimation in flood risk assessment, $\mathrm{PhD}$ thesis, Delft University of Technology, The Netherlands, 2007.

Kelman, I. K.: Physical flood vulnerability of residential properties in coastal, eastern England, Dissertation submitted for the degree of Doctor of Philosophy, September 2002, University of Cambridge, UK, 2002.

Kolen, B., Slomp, R., van Balen, W., Terpstra, T., Bottema, M., and Nieuwenhuis, S.: Learning from French experiences with storm Xynthia - Damages after a flood ISBN 978-90-77051-771 September 2010, 2010.

Kraus, N.: The history and heritage of coastal engineering, published by the American Society of Civil Engineers, ISBN 07844-0196-9, 1996.

Lafautesurmer.net: http://www.lafautesurmer.net/2011/02/25/ la-faute-sur-mer-un-an-apres-xynthia-europe-1/, last access: 8 March 2011, 2011.

Le Figaro: Xynthia coûtera au moins 1,2 milliard aux assureurs, 5 March 2010, http://www.lefigaro.fr, last access: 5 January 2011, 2010a.

Le Figaro: Les terribles leçons d'une tempête, 5 March 2010, Le Figaro Magazine, http://www.lefigaro.fr/actualite-france/, last access: 1 March 2011, 2010b.
Lumbroso, D. M. and Di Mauro, M.: Recent developments in loss of life and evacuation modelling for flood event management in the UK, in: Flood Recovery, Innovation and Response, edited by: Proverbs, D. B., Brebbia, C. A., and Penning-Rowsell, E., 263-272 WITpress, 2008.

Maxiscience: Tempête Xynthia : un plan digue sera présenté d'ici à deux mois, http://www.maxisciences.com/, last access: 1 March 2011, 2010.

Mercier, D. and Acerra, M.: Xynthia, une tragédie prévisble, ISBN 978-2-84809-169-3, published by Place publique, France, 2011.

Ministère De L'Ecologie Et Du Développement Durable Directions Régionales De L'Environnement (MEEDDM): Tempête Xynthia - Retour d'expérience, évaluation et propositions d'action, Rapport du gouvernement français, Mai 2010, 2 Tomes, 2010.

Ministère De L'Ecologie Et Du Développement Durable Directions Régionales De L'Environnement (MEEDDM): Plan submersions rapides: Submersions marines, crues soudaines et ruptures de digues, 2011.

Muir-Wood, R., Drayton, M., Berger, A., Burgess, P., and Wright, T.: Catastrophe loss modelling of storm-surge flood risk in eastern England, Phil. Trans. R. Soc. A., 363, 1407-1422, doi:10.1098/rsta.2005.1575, 2005.

National Audit Office (NAO): Environment Agency: Building and maintaining river and coastal flood defences in England, ISBN: 9780102945522, published by the London: The Stationery Office, UK, 2007.

Office of the Deputy Prime Minister (ODPM): Projections of Households in England 2021, published 3 May 2000, updated 4 December 2000, ODPM, London, UK, 2000.

Penning-Rowsell, E., Johnson, C. and Tunstall, S.: Signals' from pre-crisis discourse: Lessons from UK ?ooding for global environmental policy change?, Global Environmental Change, 16(2006), 323-339, 2006.

Pollard, M.: North Sea Surge: The story of the East Coast Floods of 1953, Terence Dalton Limited, Lavenham and Suffolk, UK, 1978.

Risk Management Solutions (RMS): 1953 UK floods 50 year retrospective, available at: http://www.rms.com/publications/1953 Floods_Retrospective.pdf, last access: 5 January 2011, 2003.

Risk Management Solutions (RMS): 1947 UK river floods: 60 year retrospective, available at; http://www.rms.com/Reports/ 1947_UKRiverFloods.pdf, last access: 5 January 2011, 2007.

SENAT: Comptes rendus de la mission commune d'information sur les consequences de la tempete Xynthia, http://www.senat.fr/ compte-rendu-commissions/20100517/xynthia.html\#toc2, last access: 2 March 2011, 2010.

Steers, J. A.: The east coast floods, Geographical Journal 119, 280298, 1953.

Sturcke, J.: Lessons of 1953 spurred spending on flood defences, Guardian newspaper, Friday 9 November 2007, 2007.

Summers, D.: The east coast floods, Newton Abbott: David and Charles, 1978.

Waverley, J. A.: Report of the departmental committee on coastal flooding, HMSO, London, 1954. 